\title{
Characterization of Microstructure and Non-metallic Inclusions in Zr-Al Deoxidized Low Carbon Steel
}

\author{
Min JIANG, ${ }^{1)}$ Zhiyong $\mathrm{HU}^{, 2)}$ Xinhua WANG ${ }^{2)}$ and Jong-Jin $\mathrm{PAK}^{3)^{*}}$ \\ 1) Formerly University of Science and Technology Beijing. Now at Hanyang University, Ansan, $426-791$ Korea. \\ 2) University of Science and Technology Beijing, Beijing, 100083 P.R China. \\ 3) Hanyang University, Ansan, 426-791 Korea.
}

(Received on January 17, 2013; accepted on April 18, 2013)

\begin{abstract}
Laboratory experiments were carried out to investigate non-metallic inclusions and microstructures in $\mathrm{Zr}$-Al deoxidized low carbon steel. Contents of [Zr] in the steel samples were of different levels while [Al] varied in the range of $0.0012-0.0032 \%$. It was found that inclusions and the developed microstructures varied greatly with the change of $[\mathrm{Zr}]$ in steel. In the high $[\mathrm{Zr}](0.072 \%)$ steel sample with [S] about $0.012 \%$, the produced $\mathrm{ZrO}_{2}$ inclusions in deoxidization favored the uniform precipitation of $\mathrm{MnS}$ and all inclusions were composed of dual phases of $\mathrm{ZrO}_{2}+\mathrm{MnS}$. Microstructures consisted of pearlites and ferrites after water quenching directly from liquid to solid. Ferrites developed by $\mathrm{ZrO}_{2}+\mathrm{MnS}$ inclusions were not observed. With $[\mathrm{Zr}]$ at a medium level about of $0.0085 \%$ and $[\mathrm{S}]$ at about $0.012 \%$, complex $\left(\mathrm{ZrO}_{2}-\right.$ $\left.\mathrm{TiO}_{\mathrm{x}}\right)-\left(\mathrm{Al}_{2} \mathrm{O}_{3}-\mathrm{SiO}_{2}-\mathrm{MnO}-(\mathrm{MnS})\right)$ inclusions were formed. The microstructures of steel were characterized by fine and interlocked intra-granular ferrites (IAF). SEM observation indicated that those complex inclusions were good nucleation sites for IAF. In the [Zr] steel sample with low [Zr] of about $0.0008 \%$ and [S] of about $0.0017 \%$, very typical IAF was also induced by the complex $\left(\mathrm{MgO}-\mathrm{Al}_{2} \mathrm{O}_{3}-\mathrm{SiO}_{2}-\mathrm{MnO}\right)$ inclusions of very high number density.
\end{abstract}

KEY WORDS: non-metallic inclusion; Zr-Al deoxidation; low carbon steel; intra-granular ferrite.

\section{Introduction}

Heavy steel plates are widely applied for high buildings, offshore structures, pipelines and oil vessels, and so on. Control of MnS inclusions, especially morphology modification, is known to be very important because elongated $\mathrm{MnS}$ stringers after rolling degrade mechanical properties in the transverse direction and induce HIC or SCC in these low carbon steels. ${ }^{1-5)}$ Moreover, the thicknesses of these steel plates are increasing with the need for higher strength and toughness. As a result, much larger energy is input during welding for higher efficiency in fabrication. One big problem is grain coarsening in the HAZ (heat affected zone) after welding, which deteriorates toughness. ${ }^{6,7)}$ Therefore, the significance of microstructure refinement in the HAZ had been well recognized; for this problem, acicular ferrites have been found be very helpful. ${ }^{8)}$

In the 1990s, Takamura and Mizoguchi ${ }^{9,10)}$ proposed the technical concept of "oxide metallurgy" by utilizing inclusions to develop intra-granular acicular ferrites. They pointed out that inclusions with the proper chemical composition, size distribution, and number density can act as heterogeneous nucleation sites for new phases and can refine the microstructure of steel, for example, as inoculants for ferrites within prior austenite grains. ${ }^{11-18)}$ From this point of

* Corresponding author: E-mail: jjpak@hanyang.ac.kr

DOI: http://dx.doi.org/10.2355/isijinternational.53.1386 view, steel compositions, deoxidization methods, refining slags, cooling rates, etc. are very important; all of these directly affect the types, sizes and number density of inclusions.

$\mathrm{Zr}$ is an element with strong affinity to oxygen, nitrogen, sulfur, etc. in steel; any produced inclusions have great influence on steel. $\mathrm{MnS}$ inclusions were found to prefer to precipitate on complex oxides produced in $\mathrm{Si}-\mathrm{Mn}-\mathrm{Zr}$ deoxidization when Takamura et al. ${ }^{10)}$ proposed the concept of "oxide metallurgy". In recent years, Suito et al. intensively studied inclusions produced in $\mathrm{Zr}$ deoxidized carbon steel and $\mathrm{Fe}-\mathrm{Ni}$ alloys as well as the influences of inclusions on what is called microstructure refinement. ${ }^{19-27)}$ Moreover, they mainly focused on the pinning effect of inclusion at grain boundaries. Formation of intra-granular ferrites in the HAZ by inclusions in $\mathrm{Zr}$-Ti deoxidized steel was mentioned by those researchers, but much less attention was paid to the concept. ${ }^{28)}$ Chai et al. ${ }^{29)}$ reported that $\mathrm{Zr}$ addition into a Tikilled steel plate effectively refined the HAZ microstructure in ship plates after welding; they found that the formed $\mathrm{ZrO}_{2}+\mathrm{MnS}$ complex inclusions could not induce acicular ferrite. Guo et al $^{30)}$ found that the addition of $\mathrm{Zr}$ into Alkilled pipeline steel can usefully enhance the impact toughness of the HAZ in welded steel plates; however, the nucleation of intra-granular ferrites on the $\mathrm{ZrO}_{2}+\mathrm{MnS}$ dual phase inclusions was observed, which was inconsistent with the results of Chai et $a l .{ }^{29)} \mathrm{Wu}$ et al. $^{31)}$ found that the addition of $\mathrm{Zr}$ into Al-killed Ti-bearing ship plates can greatly 
Table 1. Typical Work on Zr Addition to Steel in Oxide Metallurgy in Past Two Decades.

\begin{tabular}{|c|c|c|c|c|c|c|}
\hline Year & Authors & Metal & Deoxidation & {$[\mathrm{Zr}] / \mathrm{ppm}$} & Purpose & Ref. \\
\hline 1990 & Takamura et al. & low C steel & $\mathrm{Zr}$ & 20,100 & A1 & 9 \\
\hline 1990 & Mizoguchi et al. & low C steel & $\mathrm{Zr}$ & 120 & B & 10 \\
\hline 2006 & Suito et al. & $\mathrm{Fe}-10 \% \mathrm{Ni}$ & $\mathrm{Zr}$ & $116-633$ & A1 & 19 \\
\hline 2006 & Suito et al. & $\mathrm{Fe}-10 \% \mathrm{Ni}$ & $\mathrm{Zr}$ & $87-95,1.7-99.2$ & A4 & 20,23 \\
\hline 2006 & Suito et al. & $\mathrm{Fe}-10 \% \mathrm{Ni}, \mathrm{Fe}-10 \% \mathrm{Ni}-1 \% \mathrm{Mn}$ & $\mathrm{Zr}$ & $\begin{array}{c}45.5-89.9 \\
([S]: 19-433)\end{array}$ & A4, B & 22 \\
\hline 2006 & Suito et al. & $\mathrm{Fe}-10 \% \mathrm{Ni}$ & $\mathrm{Zr}$ & $800-1200$ (target) & A1, A4 & 24 \\
\hline 2006 & Suito et al. & $\begin{array}{c}\mathrm{Fe}-10 \% \mathrm{Ni}, \mathrm{Fe}-0.5 \% \mathrm{C}-1 \% \mathrm{Mn} \\
\mathrm{Fe}-0.3 \% \mathrm{C}-1 \% \mathrm{Mn}-1 \% \mathrm{Ni} \\
\mathrm{Fe}-0.2 \% \mathrm{C}-0.02 \% \mathrm{P} \\
\mathrm{Fe}-0.15 \% \mathrm{C}-1 \% \mathrm{Mn}-1 \% \mathrm{Ni}\end{array}$ & $\mathrm{Zr}$ & $1-1080$ & C1 & 21 \\
\hline 2006 & Suito et al. & $\mathrm{Fe}-10 \% \mathrm{Ni}, \mathrm{Fe}-0.2 \% \mathrm{C}-0.02 \% \mathrm{P}$ & $\mathrm{Zr}$ & $1.3-1800$ & C1 & 25 \\
\hline 2008 & Suito et al. & $\mathrm{Fe}-10 \% \mathrm{Ni}$ & $\mathrm{Zr} / \mathrm{Ti}$ & $11-1166$ & C1 & 26 \\
\hline 2008 & Suito et al. & low $\mathrm{C}$ steel $(1 \% \mathrm{Ni})$ & $\mathrm{Zr}$ & 1,38 & $\mathrm{C} 1$ & 27 \\
\hline 2008 & Guo et al. & Pipeline steel & $\mathrm{Zr}$ & 0,150 & D & 30 \\
\hline 2011 & Suito et al. & low $\mathrm{C}$ steel & $\begin{array}{c}\mathrm{Zr}, \mathrm{Ti} / \mathrm{Zr}, \mathrm{Ti} / \mathrm{Mg} / \mathrm{Zr}, \\
\mathrm{Al}-\mathrm{Ti} / \mathrm{Zr}\end{array}$ & $\sim 233$ & $\mathrm{C} 2$ & 28 \\
\hline 2012 & Wu et al. & low C steel & Al killed $\mathrm{Zr}$ bearing & 0,100 & $\mathrm{C2}$ & 31 \\
\hline
\end{tabular}

increased the impact toughness of the HAZ. The related typical works of oxide metallurgy from the past are briefly summarized in Table 1. There have also been other studies on inclusions in steel with added Zr. For example, zirconium sulfides in resulfurized free-cutting steel were reported to minimize the aspect ratio of sulfides. ${ }^{32)}$ Zirconium carbonitrides effectively prevent austenite grain growth in Alkilled high strength low alloy steel and low carbon bainite steel. ${ }^{33-36)}$ By comparison, zirconium oxides formed in $\mathrm{Zr}$ deoxidization were much more intensively studied.

Therefore, there have been many works on inclusions in $\mathrm{Zr}$ deoxidized steel and some studies for $\mathrm{Ti}-\mathrm{Zr}$ and $\mathrm{Al}-\mathrm{Zr}$ complex deoxidized steels. The produced inclusions in $\mathrm{Zr}$ deoxidization were proved to be very effective in pinning the grains. By comparison, the effects of inclusions on the development of intra-granular ferrites were much less studied. Moreover, it is particularly well known that aluminum is usually contained in alloys; aluminum can greatly affect the formation of inclusions, and thus probably the microstructure refinement of steel. Although the effect of the addition of $\mathrm{Zr}$ in Al-killed low carbon steel on the toughness has been studied, the formation of inclusions in $\mathrm{Zr}-\mathrm{Al}$ complex deoxidization can be expected to be different and studies on inclusion influence on the microstructures have been only rarely seen. Furthermore, there are some disagreements on observation results on the effects of $\mathrm{ZrO}_{2}+\mathrm{MnS}$ complex inclusions on the development of intra-granular ferrites. As a result, experiments were undertaken in the present study to investigate the effects of the produced inclusions in $\mathrm{Zr}-$ $\mathrm{Al}$ deoxidization in low carbon steel; the microstructures of the steel were also characterized.

\section{Experimental Procedures}

Experiments were carried out in a vertical electrical resistance furnace with $\mathrm{MoSi}_{2}$ heating bars. Three experiments were performed; one of them involved slag refining (50 g, $\mathrm{CaO}-\mathrm{SiO}_{2}-\mathrm{Al}_{2} \mathrm{O}_{3}$ ternary slag with basicity about 2.5 and $\mathrm{Al}_{2} \mathrm{O}_{3}$ about $25 \%$ ). During the experiments, high purity argon gas flow was introduced into a sealed $\mathrm{Al}_{2} \mathrm{O}_{3}$ reaction tube at all times. In each experiment, $1 \mathrm{~kg}$ of electrolyte $\mathrm{Fe}$ was charged into a $\mathrm{MgO}$ crucible and set at the even temperature zone of the furnace. When the melt was heated to $1873 \mathrm{~K}, \mathrm{Fe}_{2} \mathrm{O}_{3}$ powder was added into the melt to increase the initial oxygen in the melt. Then, $\mathrm{Zr}$ and $\mathrm{Fe}-\mathrm{Al}-\mathrm{Mn}$ alloys were added for deoxidization. About twenty minutes after deoxidation, alloys like $\mathrm{FeC}$, electrolyte $\mathrm{Mn}, \mathrm{FeS}$, crystal silicon, etc. were added into the steel melt for composition adjustment. After homogeneity of chemical composition was achieved, the crucible was taken out of the furnace and water quenched rapidly with a cooling rate estimated at about $15 \mathrm{~K} / \mathrm{s}$. For the estimation of the cooling speed, a special experiment was done in which a thermocouple was inserted into the cooling sample to record the change of temperature with time, with results as shown in Fig. 1. Because the sample had to be picked up from the tube before it was put into water for quenching, the measurement was started from about $1508^{\circ} \mathrm{C}$, when the thermocouple was inserted into the sample.

The obtained steel samples were prepared for chemistry analysis, inclusion inspection, and microstructure observation. Soluble contents of $\mathrm{Al}$ and $\mathrm{Zr}$ were measured using ICP method. Compositions in this article are all given in weight percentage unless specifically stated. Disc samples were transversely sectioned and mirror polished for inclu- 


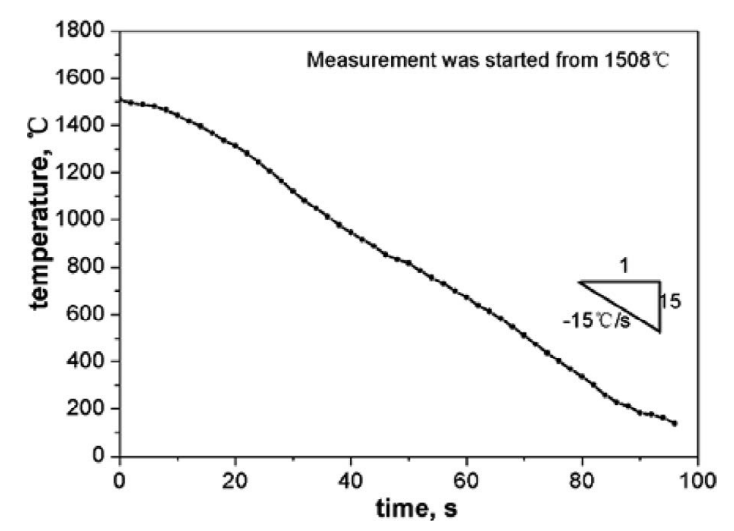

Fig. 1. Change of temperature with time of the sample during water quenching from liquid to solid.

Table 2. Chemical Compositions of Steel Samples.

\begin{tabular}{lccccccc}
\hline \multirow{2}{*}{ Sample } & \multicolumn{7}{c}{ Contents (mass\%) } \\
\cline { 2 - 7 } & $\mathrm{C}$ & $\mathrm{Si}$ & $\mathrm{Mn}$ & $\mathrm{S}$ & $\mathrm{Al}$ & $\mathrm{Zr}$ & Slag refining \\
\hline High Zr & 0.15 & 0.24 & 1.01 & 0.0120 & 0.0012 & 0.0720 & No \\
Medium Zr & 0.08 & 0.20 & 0.98 & 0.0120 & 0.0024 & 0.0085 & No \\
Low Zr & 0.17 & 0.12 & 0.92 & 0.0017 & 0.0032 & 0.0008 & Yes \\
\hline
\end{tabular}

sion inspection using an automatic secondary electron microscope with energy disperse spectrum (ASPEX PSEM Explorer). Microstructures of the samples etched by $3 \%$ Natal solution were observed by both optical microscope (LEICA DM6000M) and SEM methods.

\section{Results and Discussion}

\subsection{Chemical Compositions of Steel Samples}

Chemical compositions of the steel samples are given in Table 2. [Al] contents in the three samples are 0.0012 , 0.0024 , and $0.0032 \%$. The [Zr] contents are $0.0720,0.0085$, and $0.0008 \%$, respectively. Thus, the samples are classified as high $\mathrm{Zr}$, medium $\mathrm{Zr}$, and low $\mathrm{Zr}$ samples in the present paper. Because of the top slag refining, sulfur content in the low $\mathrm{Zr}$ steel sample is much lower than that in the other two steel samples.

\subsection{Characterization of Microstructures}

Optical microstructures of the steel samples are presented in Figs. 2, 3 and 4. It can be seen that microstructures of the three steel samples mainly consisted of ferrites. However, the morphology of the formed ferrites in three samples is distinctive according to the level of $\mathrm{Zr}$ contents. In the high $\mathrm{Zr}$ sample, ferrites are in chaotically polygonal shapes, with sizes usually more than 200-300 $\mu \mathrm{m}$, as shown in Fig. 2. In the medium $\mathrm{Zr}$ sample, very fine acicular ferrites were found to hvae developed; these are called inters. Some polygonal shaped ferrites are also observed, as shown in Fig. 3(a). Images of higher magnification indicate that these acicular ferrites appeared as interwoven long strips, as shown in Fig. 3(b). In the low Zr sample, interlocked lenticular shaped ferrites formed with prior austenite grains are the main feature of the microstructure. Sheaf morphology side plate ferrites and polygonal allotrimorphic ferrites nucleated and developed from the prior austenite grain

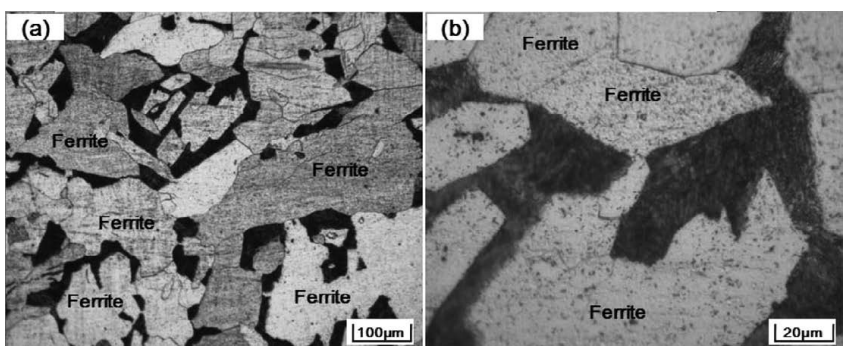

Fig. 2. Microstructures of high $\mathrm{Zr}$ sample: (a) lower magnification, (b) higher magnification.
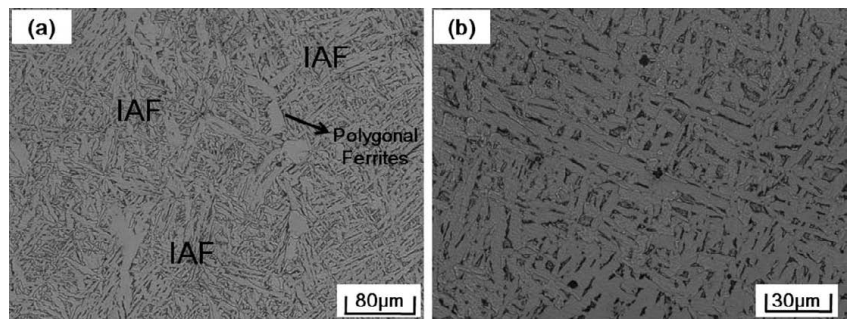

Fig. 3. Microstructures of medium $\mathrm{Zr}$ sample: (a) lower magnification, (b) higher magnification.
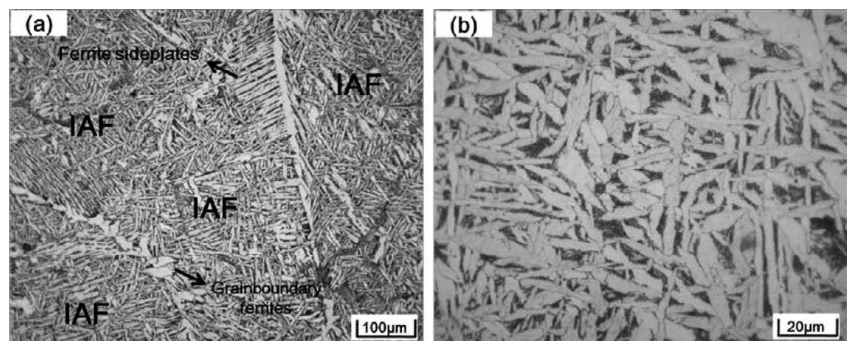

Fig. 4. Microstructures of low Zr sample: (a) lower magnification, (b) higher magnification.

boundaries are also formed in this sample, but they are only a small fraction, as shown in Fig. 4(a). These lenticular shaped ferrites have different growth orientations and, with two dimensional size of mainly less than $50 \mu \mathrm{m}$, resulted in an intersecting image under optical microscope observation, as shown in Fig. 4(b) at larger magnification.

\subsection{Nucleation of Ferrites at Non-metallic Inclusions}

Nucleation of ferrites on non-metallic inclusions was observed in the medium $\mathrm{Zr}$ sample and the low $\mathrm{Zr}$ sample, while it was not detected in the high $\mathrm{Zr}$ steel sample. Figure 5 shows the observation results of the microstructure by SEM; Fig. 5(a) provides an image under back scattering mode. As can be seen, the ferrites in the high $\mathrm{Zr}$ steel sample were very large in size and in irregular polygonal shapes. In particular, nucleating of ferrites on inclusions was not observed in this steel sample. However, by contrast, the development of ferrites by inclusions was observed frequently in the medium $\mathrm{Zr}$ steel sample and the low $\mathrm{Zr}$ steel sample. As shown in Fig. 5(b), the inclusion at about $2 \mu \mathrm{m}$ acted as the heterogeneous nucleus of the ferrites. EDS results indicate that, in terms of overall chemistry, the inclusion was composed of $\mathrm{ZrO}_{2}-\mathrm{TiO}_{\mathrm{x}}-\mathrm{SiO}_{2}-\mathrm{MnO}$. The inclusion shown in Fig. 5(c) was a little larger, at about 4-5 $\mu \mathrm{m}$; ferrite laths developed from it and grew in a radiative way. 


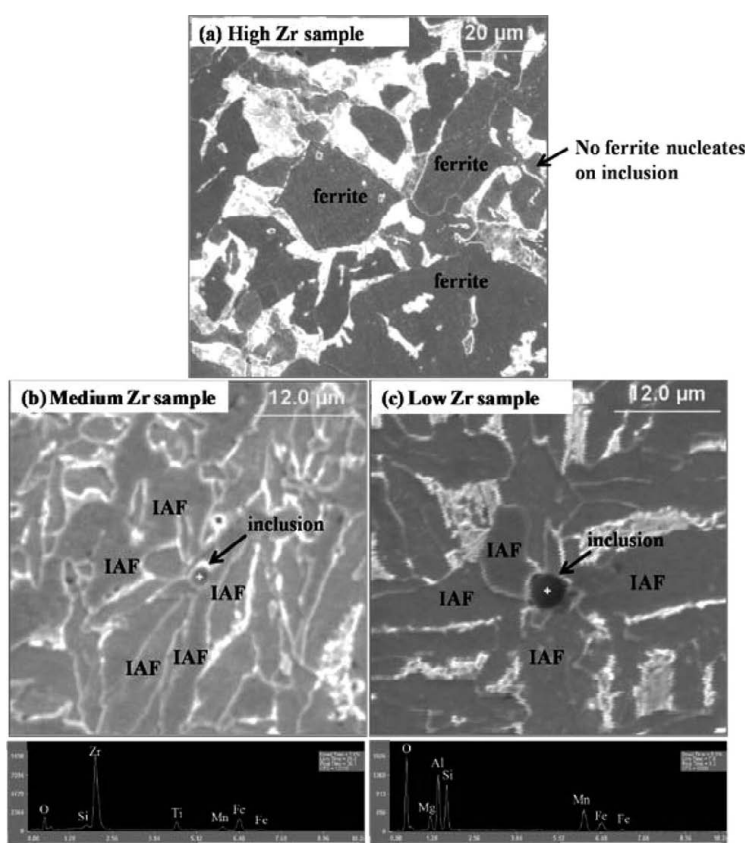

Fig. 5. Observation of nucleation of ferrites on inclusion in high $\mathrm{Zr}$, medium $\mathrm{Zr}$, and low $\mathrm{Zr}$ steel samples.

Based on the EDS peaks, it can be seen that the chemistry of this inclusion was also very complex, and that it was composed of an $\mathrm{MgO}-\mathrm{Al}_{2} \mathrm{O}_{3}-\mathrm{SiO}_{2}-\mathrm{MnO}$ system.

It is particularly known that the formation of IAF is very complex. Several factors can contribute to the formation process, including steel additives like [C], [Si] and [Mn], and inclusions and thermal cycles of the steel, such as cooling rate. In conventional heat treatment, prior austenite grain size also plays an important role during the phase transformation between $\alpha$-Fe and $\gamma$-Fe. In the present experiments, the chemical compositions of the steel were not completely the same in terms of [C] and [Si]. Nevertheless, in the high $\mathrm{Zr}$ steel sample and the medium $\mathrm{Zr}$ steel sample, the compositions were very similar except for the levels of carbon, which were about 0.15 and $0.08 \%$, respectively. Therefore, it can be predicted that $\mathrm{L}-\delta-\gamma-\alpha$ phase transformations will occur in both samples during quenching. Other factors, like solidification related parameters, could be considered the same. However, as mentioned in the sections above, the microstructures in the high $\mathrm{Zr}$ and the medium $\mathrm{Zr}$ samples were completely distinctive. As result, it can be cautiously but reasonably asserted that non-metallic inclusions were the main reason contributing to the big differences in microstructures of the three samples.

\subsection{Comparison of the Formed Non-metallic Inclu- sions: Chemistry, Size Distribution and Number Density}

Using an automatic SEM EDS (ASPEX Explorer), a large area on the surface of each sample was selected for inclusion inspection. About 4000 inclusions were randomly inspected in each sample. Thus, their important characteristics, such as the sizes, chemistry, and number density were obtained. SEM-EDS analysis results of inclusions in the three steel samples are given in Figs. 6, 7, and 8, respectively. It can be seen that the chemistry of the inclusions varied with the change of $\mathrm{Zr}$ contents in the three steel samples. In

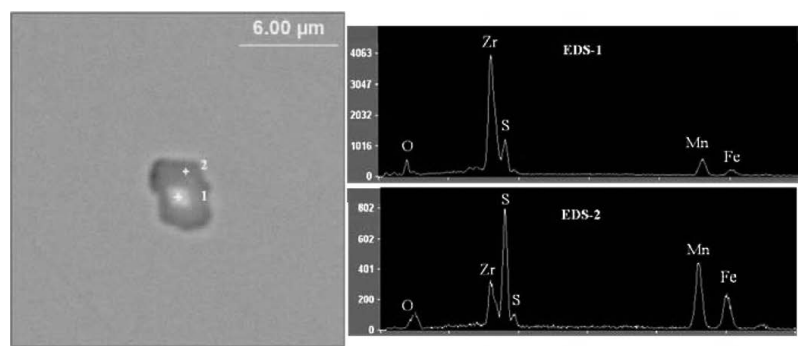

Fig. 6. Typical inclusion in high $\mathrm{Zr}$ steel sample: $\mathrm{ZrO}_{2}+\mathrm{MnS}$.

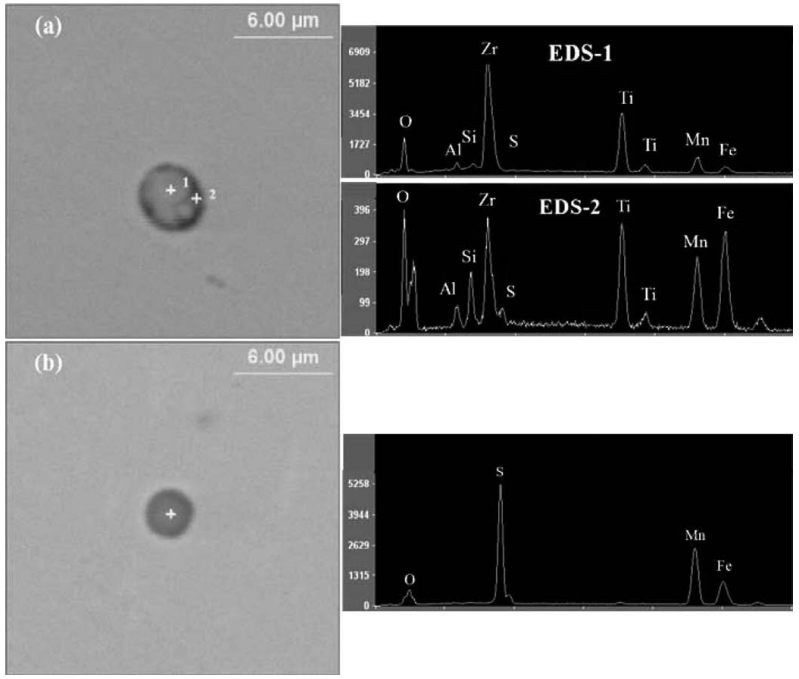

Fig. 7. Typical inclusions in medium $\mathrm{Zr}$ steel sample: (a) $\left(\mathrm{ZrO}_{2}-\right.$ $\left.\mathrm{TiO}_{\mathrm{x}}\right)-\left(\mathrm{Al}_{2} \mathrm{O}_{3}-\mathrm{SiO}_{2}-\mathrm{MnO}-(\mathrm{MnS})\right)$, (b) $\mathrm{MnS}$.

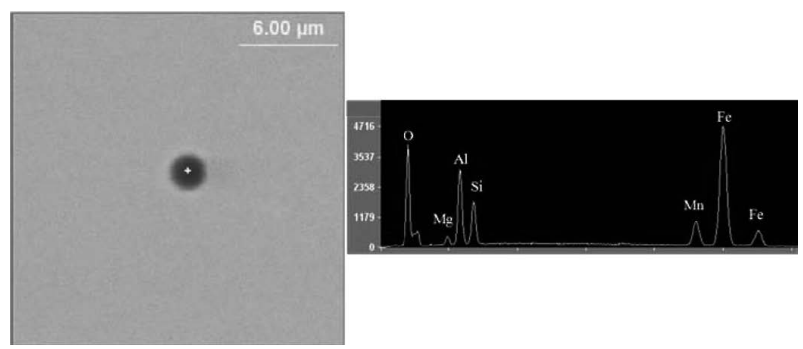

Fig. 8. Typical inclusion in low $\mathrm{Zr}$ steel sample: $\left(\mathrm{MgO}-\mathrm{Al}_{2} \mathrm{O}_{3}-\right.$ $\mathrm{SiO}_{2}-\mathrm{MnO}$ )

the high $\mathrm{Zr}$ steel sample, all the detected inclusions are found to consist of dual phases, viz., with polygonal $\mathrm{ZrO}_{2}$ in the center wrapped by an $\mathrm{MnS}$ outer skin, as shown in Fig. 6. This result agrees with that reported by Mizoguchi et al., ${ }^{10,18)}$ who found that $\mathrm{MnS}$ preferred to precipitate on $\mathrm{ZrO}_{2}$, resulting in finer sizes and uniform dispersion. This phenomenon can be attributed to the similar lattice parameters and good lattice coherence between $\mathrm{MnS}$ and $\mathrm{ZrO}_{2}$ [30]. It means that although no IAF was developed at high $\mathrm{Zr}$ content in steel, the formed $\mathrm{ZrO}_{2}$ inclusions were still very useful in controlling the precipitation of $\mathrm{MnS}$, which is also very important for heavy steel plates.

In the medium $\mathrm{Zr}$ steel sample, two kinds of inclusions were detected. The majority of them were complex in chemistry, characterized by $\mathrm{ZrO}_{2}-\mathrm{TiO}_{\mathrm{x}}$ inclusion surrounded with an $\mathrm{Al}_{2} \mathrm{O}_{3}-\mathrm{SiO}_{2}-\mathrm{MnO}-(\mathrm{MnS})$ surface layer, as shown in Fig. 7(a); the central part of this kind of inclusion had higher $\mathrm{Zr}$ 
and $\mathrm{Ti}$ and less $\mathrm{Si}, \mathrm{Mn}, \mathrm{Al}$, and $\mathrm{S}$; the outer part had higher $\mathrm{Si}, \mathrm{Mn}, \mathrm{Al}, \mathrm{O}$, and $\mathrm{S}$ and lower levels of $\mathrm{Zr}$ and Ti. Titanium was not added in the present study. Therefore, the source of titanium observed in inclusions may be from the added alloys as impurity. The other kind of inclusions was single $\mathrm{MnS}$, but these occupied a small fraction. The single MnS had spherical or near-spherical shape, as shown in Fig. 7(b). It also can be found that although the sulfur contents were the same in the high $\mathrm{Zr}$ and medium $\mathrm{Zr}$ steel samples, no singular $\mathrm{MnS}$ inclusions were formed in the high $\mathrm{Zr}$ steel sample, which means that $\mathrm{ZrO}_{2}$ actually was very helpful in preventing formation of $\mathrm{MnS}$ which can form elongated strings after rolling and which is very negative for heavy steel plates.

With zirconium content greatly decreased to $0.0008 \%$ in the low $\mathrm{Zr}$ steel sample, no $\mathrm{ZrO}_{2}$ is contained in the inclusions. The inclusions are mainly composed of the $\mathrm{MgO}-$ $\mathrm{Al}_{2} \mathrm{O}_{3}-\mathrm{SiO}_{2}-\mathrm{MnO}$ system; $\mathrm{MnS}$ was seldom detected in inclusions because of the very low sulfur content in the steel. Distinctive from inclusions in the high $\mathrm{Zr}$ and medium $\mathrm{Zr}$ samples, inclusions in the low $\mathrm{Zr}$ sample are homogeneous, as indicated in Fig. 8.

Size distributions of inclusions were also analyzed and results are shown in Fig. 9. As can be seen, the size of inclusions in the three steel samples are mainly within $5 \mu \mathrm{m}$. Percentages of inclusions within $1 \mu \mathrm{m}$ in high $\mathrm{Zr}$, medium $\mathrm{Zr}$, and low $\mathrm{Zr}$ were about 12, 3 and $12 \%$, respectively. Fraction of inclusions in the range of $1-5 \mu \mathrm{m}$ occupied the largest

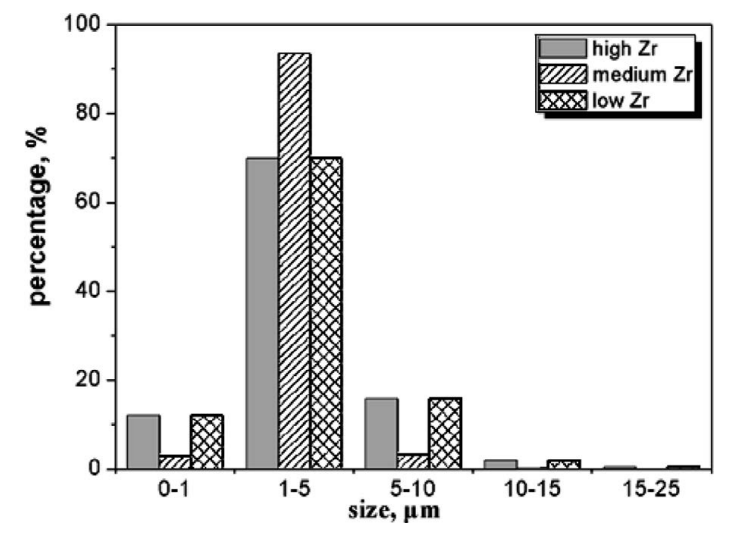

Fig. 9. Size distribution of inclusions in high $\mathrm{Zr}$, medium $\mathrm{Zr}$, and low $\mathrm{Zr}$ steel samples.

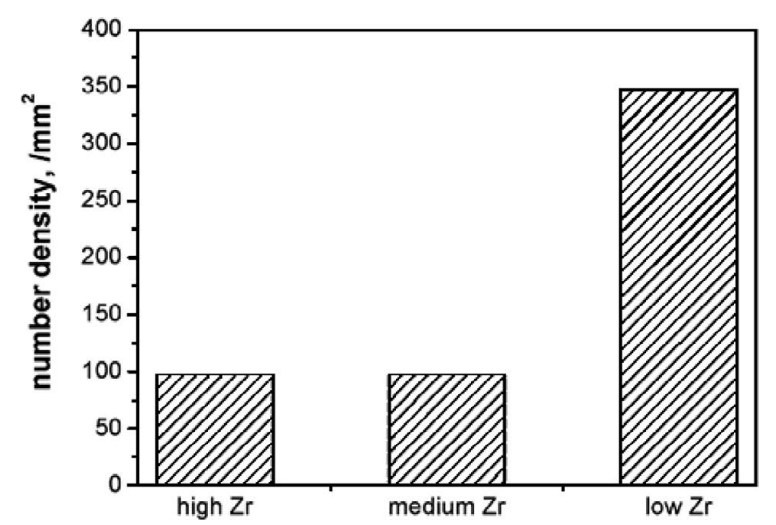

Fig. 10. Number density of inclusions in high $\mathrm{Zr}$, medium $\mathrm{Zr}$, and low $\mathrm{Zr}$ steel samples. proportions in all the steel samples, or about $93 \%$ in the medium $\mathrm{Zr}$ steel sample and about $70 \%$ in the other two samples. Inclusions with size varying in the range of 5-10 $\mu \mathrm{m}$ are about 16,3 and $16 \%$ in high $\mathrm{Zr}$, medium $\mathrm{Zr}$, and low $\mathrm{Zr}$, respectively while inclusions with size exceeding this range are very rare. Number density of inclusions in the steel samples was compared, with results given in Fig. 10, this data was estimated by dividing the total number of inclusions by the observed area. As can be seen, number density of inclusions was about 97 per $\mathrm{mm}^{2}$ in both the high and medium $\mathrm{Zr}$ steel samples. However, inclusion number density was much high in the low $\mathrm{Zr}$ steel sample, at about 347 per $\mathrm{mm}^{2}$.

Hence, the inclusions in the three samples mainly had sizes in the range of $1-5 \mu \mathrm{m}$. This means that the size of the inclusions was not the main reason for the difference in the development of IAF by inclusions. As the number density of the inclusions was nearly the same in the high $\mathrm{Zr}$ sample and the medium $\mathrm{Zr}$ sample, it can be reasonably inferred that the inclusion chemistry is responsible for there being no IAF in the high $\mathrm{Zr}$ sample while there is good IAF in the sample with a medium level of $\mathrm{Zr}$. Therefore, it can be inferred that $\left(\mathrm{ZrO}_{2}-\mathrm{TiO}_{\mathrm{x}}\right)-\left(\mathrm{SiO}_{2}-\mathrm{MnO}-\mathrm{Al}_{2} \mathrm{O}_{3}-(\mathrm{MnS})\right)$ inclusions in the medium $\mathrm{Zr}$ steel sample are useful in developing ferrites. Although $\mathrm{ZrO}_{2}+\mathrm{MnS}$ inclusions cannot induce intra-granular ferrite in the high $\mathrm{Zr}$ steel sample, there are very good heterogeneous nucleation sites for $\mathrm{MnS}$. By comparison, it is not so clear that whether it is number density or chemistry of inclusion in the low $\mathrm{Zr}$ steel sample that contributes more to the formation of IAF. On the other hand, it can be seen from the results that the lower level of $[\mathrm{Zr}]$ in the steel was definitely not bad for the development of intra-granular ferrite. Moreover, further investigations are needed to elucidate the optimized steel chemistry for IAF in $\mathrm{Zr}$ containing steel.

\section{Conclusions}

Experiments were carried out in the lab to investigate the development of intra-granular acicular ferrite (IAF) by inclusions in $\mathrm{Zr}-\mathrm{Al}$ deoxidized steel microstructure refinement. Three samples were used with different contents of $[\mathrm{Zr}]$ while $[\mathrm{Al}]$ varied in the range of $0.0012-0.0032 \%$. The results are summarized as follows.

(1) In the steel sample with high [Zr] of about $0.072 \%$, the formed inclusions are mainly $\mathrm{ZrO}_{2}$; these are good heterogeneous nucleation sites for $\mathrm{MnS}$ precipitation during solidification but are not potent for the development of IAF. The microstructure was found not to consist of IAF.

(2) In the medium steel sample with $[\mathrm{Zr}]$ of about $0.0085 \%$, the produced inclusions were mainly complex $\left(\mathrm{ZrO}_{2}-\mathrm{TiO}_{\mathrm{x}}\right)-\left(\mathrm{SiO}_{2}-\mathrm{MnO}-\mathrm{Al}_{2} \mathrm{O}_{3}-(\mathrm{MnS})\right)$ inclusions and some singular $\mathrm{MnS}$ inclusions. The formed $\left(\mathrm{ZrO}_{2}-\mathrm{TiO}_{\mathrm{x}}\right)_{-}$ $\left(\mathrm{SiO}_{2}-\mathrm{MnO}-\mathrm{Al}_{2} \mathrm{O}_{3}-(\mathrm{MnS})\right)$ inclusions are good nucleation sites for IAF. As a result, very fine interwoven acicular ferrites were found to have developed.

(3) In the low $\mathrm{Zr}$ steel sample with $[\mathrm{Zr}]$ of about $0.0008 \%, \quad \mathrm{MgO}-\mathrm{Al}_{2} \mathrm{O}_{3}-\mathrm{SiO}_{2}-\mathrm{MnO}$ complex inclusions were produced with a very high number density of about 347 per $\mathrm{mm}^{2}$. The formed inclusions also induced very nice IAF in the steel. 


\section{REFERENCES}

1) W. K. Kim, H. G. Jung, G. T. Park, S. U. Koh and K. Y. Kim: Scr. Mater., 62 (2010), 195.

2) F. Huang, J. Liu, Z. J. Deng, J. H. Cheng, Z. H. Lu and X. G. Li: Mater. Sci. Eng. A, 527 (2010), 6997.

3) O. E. Vega, A. Villagómez, J. M. Hallen and A. Contreras: Corros. Eng. Sci. Technol., 44 (2009), 289.

4) J. H. Payer, S. P. Pednekar and W. K. Boyd: Metall. Trans. A, 17A (1986), 1601.

5) M. Iino: Metall. Trans. A, 10A (1979), 1691.

6) A. Kojima, K. I. Yoshi, T. Hada, O. Saeki, K. Ichikawa, Y. Yoshida, Y. Shimura and K. Azuma: JFE Tech. Rep., 90 (2004), 39.

7) K. Hayashi, S. Fujisawa and I. Nakagawa: JFE Tech. Rep., 5 (2005), 53

8) H. Homma, S. Ohkita, S. Matsuda and K. Yamamoto: Welding J., 66 (1987), 301s.

9) J. Takamura and S. Mizoguchi: Proc. 6th Int. Iron Steel Cong., ISIJ, Tokyo, 1 (1990), 591.

10) S. Mizoguchi and J. Takamura: Proc. 6th Int. Iron Steel Cong., ISIJ, Tokyo, 1 (1990), 598.

11) Y. Tomita, N. Saito, T. Tsuzuki, Y. Tokunaga and K. Okamoto: ISIJ Int., 34 (1994), 829.

12) J. J. Pak, J. O. Jo, S. I. Kim and W. Y. Kim: ISIJ Int., 47 (2007), 16.

13) S. Suzuki, K. Ichimiya and T. Akita: JFE Tech. Rep., 5 (2005), 24.

14) F. J. Barbaro, P. Krauklis and K. E. Easterling: Mater. Sci. Technol., 5 (1989), 1057

15) T. K. Lee, H. J. Kim, B. Y. Kang and S. K. Hwang: ISIJ Int., 40
(2000), 1260.

16) Z. Zhang and R. A. Farrar: Mater. Sci. Technol., 12 (1996), 237.

17) Y. Oh, S. Lee, J. Byun, J. Shim and Y. Cho: Mater. Trans. JIM, 41 (2000), 1663.

18) T. Sawai, M. Wakoh, Y. Ueshima and S. Mizoguchi: Proc. 6th Int. Iron Steel Congress, ISIJ, Tokyo, 1 (1990), 605

19) H. Ohta and H. Suito: ISIJ Int., 46 (2006), 14

20) H. Ohta and H. Suito: ISIJ Int., 46 (2006), 22.

21) H. Suito, H. Ohta, and S. Morioka: ISIJ Int., 46 (2006), 840.

22) H. Ohta and H. Suito: ISIJ Int., 46 (2006), 480.

23) H. Ohta and H. Suito: ISIJ Int., 46 (2006), 472.

24) A. V. Karasev and H. Suito: ISIJ Int., 46 (2006), 718.

25) H. Ohta and H. Suito: ISIJ Int., 46 (2006), 832.

26) A. V. Karasev and H. Suito: ISIJ Int., 48 (2008), 1507.

27) S. Morioka and H. Suito: ISIJ Int., 48 (2008), 286.

28) H. Suito, A. V. Karasev, M. Hamada, R. Inoue and K. J. Nakajima: ISIJ Int., 51 (2011), 1151.

29) F. Chai, C. F. Yang, H. Su, Y. Q. Zhang, Z. Xu and Y. H. Yang: Acta Metall. Sin., 21 (2008), 220 (in English).

30) A. M. Guo, S. R. Li, J. Guo, P. H. Li, Q. F. Ding, K. M. Wu and X. L. He: Mater. Charact., 59 (2008), 134.

31) H. B. Wu, M. Hou, G. L. Liang and D. Tang: J. University Sci. Technol. Beijing, 34 (2012), 137.

32) K. Kato: Tetsu-to-Hagané, 48 (1962), 753.

33) K. He and T. N. Baker: Mater. Sci. Eng. A, 256 (1998), 111.

34) H. Kejian and T. N. Baker: Mater. Sci. Eng. A, 215 (1996), 57

35) D. Bhattacharya: Metall. Trans. A, 12A (1981), 973.

36) J. Guo, C. J. Shang, A. M. Guo, H. Guo, S. W. Yang and X. L. He: J. University Sci. \& Technol. Beijing, 30 (2008), 1236 